\title{
A study of radiant cooling for a room with daytime application in tropical climate
}

\author{
Satinee Wongkee, Surapong Chirarattananon, Pipat Chaiwiwatworakul ${ }^{*}$ \\ The Joint Graduate School of Energy and Environment King Mongkut's University of Technology Thonburi, \\ Bangkok 10140, Thailand
}

\begin{abstract}
Radiant cooling is an energy-efficient approach of air-conditioning that is implemented successfully intemperate climate zones. However, in hot and humid climate of the tropics, application of radiant cooling is quite challenge due to (i) its limited cooling capacity by high-moisture ambient air and (ii) the problem of moisture condensation on the cooled radiant panels. This paper reports study results of radiant cooling in a room with daytime application in the tropical climate zone. The study comprises physical experiments of a radiant cooling system that the cool panels were installed in a room of a laboratory building. A fan coil unit was also equipped in the room in order to remove moisture from the room air by ventilation. In the study, TRNSYS simulation software was used to model the systems and to determine the heat extraction rate of the cool panels. Thermal comfort level in the room was evaluated by predicted mean vote (PMV) index. The results show that the radiant cooling is able to be used for air conditioning to achieve human comfort for buildings in tropical zone.
\end{abstract}

Keywords: Radiant cooling, thermal comfort, $P$ redicted mean vote, Tropical climate.

\section{Introduction}

Thailand is located in a tropical region and is subject to hot and humid climate. Having reached saturation in commercial buildings, air-conditioning by cooling is growing rapidly in residential houses. This causes for a concern because the air-conditioning is highly energy-intensive. Currently, airconditioning system is based on circulation of cooled dry air throughout the (enclosed) air-conditioned zone or space to remove sensible (and some latent) heat from human body and from other bodies in the space.

Radiant cooling system is an alternative air-conditioning that uses cool panels to handle sensible heat from the space by radiative heat exchange. The cool panels also receive partly sensible heat due to natural circulation of the air in the space. Radiant cooling requires a separate air dehumidification system to deal with latent loads from the space and air ventilation. Radiant cooling systems have been used widely and successfully in North America and Europe where the climate is relatively dry [1-5]. In radiant cooling system, the cool panels receive thermal radiation load and some heat convected to it from ventilation air [6]. However, radiant cooling to achieve thermal comfort is very challenge in hot and humid climate; the attempt to avoid condensation of moisture from air limits cooling capacity of a radiant cooling panel and incapacitates the system against latent load.

This paper reports a study on application of radiant cooling with dehumidified ventilation under Thailand's tropical climate. For experimental investigation, a radiant cooling system was constructed at a laboratory room in Bang Khun Tien Campus, King Mongkut's university of Technology Thonburi (KMUTT). Experiments were performed with intensive measurements to evaluate the system cooling load and the thermal comfort condition. A well-known simulation program namely TRNSYS was used to simulate the operation of the radiant cooling system. The results were compared with those from the

\footnotetext{
* Manuscript received September 4, 2013; revised November 4, 2013.

Corresponding author. Tel.: + 66-2-4708309 to 10 \#4147; E-mail address: surapong@jgsee.kmutt.ac.th.
} 
experiments. TRNSYS was also used to simulate the operations of the radiant cooling system using the whole year tropical climate data. The study results demonstrate that the radiant cooling with dehumidified ventilation can enhance the performance of the radiant cooling system and improve thermal comfort level in the space.

\section{Experimental Setup}

A single-story, cross-shape building with gable roofs was the experimental site of the study. The building was located in Bang Khun Tian campus of KMUTT University, southwest suburban of Bangkok (latitude $13.57^{\circ} \mathrm{N}$ and longitude $100.44^{\circ} \mathrm{E}$ ). In order to minimize external heat gain, exterior walls of the experimental building was heavily insulated with three-inch polyurethane (PU) foam. All interior walls were also insulated with the same type of insulation of one-inch thickness. Three-inch fiberglass matt was laid over the ceiling to prevent the heat gain from roof.

In the building, one room was arranged for experiments of radiant cooling (see Fig. 1(a)). The radiant room has interior dimensions of $2.85 \mathrm{~m}$ width, $2.85 \mathrm{~m}$ length and $2.65 \mathrm{~m}$ height. . The radiant room had a 6 $\mathrm{mm}$ thick green tinted glaze window with external horizontal shading slats on the north wall. The window has a dimension of $1.5 \mathrm{~m}$ height and $2.2 \mathrm{~m}$ width. The window sill was $0.75 \mathrm{~m}$ above the floor. The room was equipped with two radiant cooling $(\mathrm{RC})$ panels; one under the room ceiling and the other one on the west wall. Fig. 1(b) shows the configuration of the radiant panels



(a) Experimental building

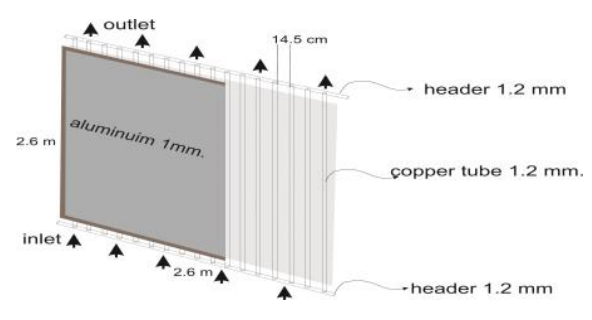

(b) Radiant cooling (RC) panel

Fig. 1. Experimental building and radiant cooling panel

As shown in Fig. 1(a), a heat pump with cooling capacity of $12.3 \mathrm{~kW}_{\text {th }}$ (3.5 refrigeration tons) was installed and used to produce chilled water at $17^{\circ} \mathrm{C}$ for cooling in the building. A 100-liter buffer tank was equipped in the chilled water loop in order to stabilize the temperature of the chilled water supply. Not be used directly for the radiant cooling, chilled water from the tank was supplied to the primary side of a heat exchanger to produce chilled water at higher temperature (e.g. $20-25^{\circ} \mathrm{C}$ ) on the secondary side. A solenoid valve was used to regulate the chilled water flow from the tank based on the measured temperature of the chilled water on the secondary side.

In the radiant room a wooden box with human-like shape was made to represent a person staying in the room. In the box, six sets of $36 \mathrm{~W}$ fluorescent lamps with $6 \mathrm{~W}$ ballast were placed to generate internal heat load. It was assumed that all electrical energy supplied to lamps was converted to heat. So the total internal heat load in the radiant room was $252 \mathrm{~W}(6 \mathrm{x}(36+6))$. From measurement, surface temperature of the box was $33^{\circ} \mathrm{C}$ when all the lamps were switched on.

A number of sensors were installed in the radiant room. Data from the sensors were transmitted to the signal conversion panels and stored in a personal computer at every minute.

- Temperature of surfaces: Surface temperatures in the radiant room (walls, floor, ceiling, and radiant panels) were measured by PT-100 sensors. Each sensor was placed at center of the surfaces and the measured values were considered as representative temperature of the whole surface.

- Air flow: The rate of natural airflow in RC room was measured manually using a hot-wire anemometer and was recorded manually. 
- Heat flow: The rates of heat flow through RC panels and selected walls were measured by heat flux sensors attached on the panel surfaces. The sensors were placed close to temperature sensors.

- Water flow: Water meters were installed to measure the amount of chilled water consumed during the experiments by the two RC panels. Two rotameters were installed later to measure the rates of chilled water flow supplied to each RC panel.

The measured data from the experiments were used to determine the heat extraction rate at the radiant panels. The data were also used to evaluate the thermal comfort level in terms of PMV derived based on International Standards Organization's procedure in standards document EN ISO 7730-1995 [7]. Ranges of PMV for thermal comfort conditions are as follow:

$\begin{array}{ll}\text { Comfortable } & -0.5 \text { to } 0.5 \\ \text { Warm } & 0.5 \text { to } 1.0 \\ \text { Cool } & -1.0 \text { to }-0.5 \\ \text { Unacceptably warm } & \text { Over } 1.0 \\ \text { Unacceptably cool } & \text { Under }-1.0\end{array}$

\section{TRNSYS Modelling}

TRNSYS program was employed to simulate operation of the cooling panels in the radiant room under the conditions of the experiments and under other defined conditions for this study. Module 56 of TRNSYS was used extensively for simulation. Input weather file is processed by a radiation processor module to produce incident solar radiation on the exterior wall surfaces of the rooms. Module 56 also calculates heat gain through walls and through window via energy balance, using given input weather data and solar radiation. It defines an air node and computes convective heat exchanges. Radiative heat exchanges between surfaces in the zone and contribution from loads in the zone are accounted for. The operative temperature, that is the weighted temperature of the mean radiant temperature of the surfaces in a zone and dry-bulb temperature of air, is also calculated. This operative temperature forms a part of comfort index that this module also outputs. TRNSYS also adopts International Standards Organization's procedure for PMV computation.

\section{Results and Discussions}

\subsection{Experimental results}

Only results from the experiment conducted on $3^{\text {rd }}$ May 2013 are chosen to present. Fig. 2(a) exhibits the solar radiations and ambient air condition on the experimental day. The sky was quite clear and the global radiation $\left(E_{\text {eg }}\right)$ varied smoothly with a peak of $900 \mathrm{~W} / \mathrm{m}^{2}$ at noon. Temperature of the ambient air $\left(\mathrm{T}_{\mathrm{amb}}\right.$ ) varied between $31^{\circ} \mathrm{C}$ and $40^{\circ} \mathrm{C}$ and absolute humidity $\left(\mathrm{W}_{\mathrm{amb}}\right)$ was about $14-17 \mathrm{~g}_{\mathrm{w}} / \mathrm{kg}_{\mathrm{da}}$.

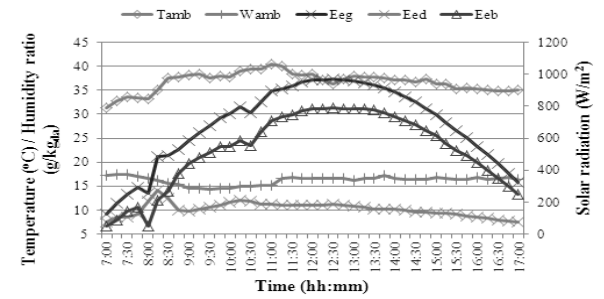

(a) Solar radiation and ambient air

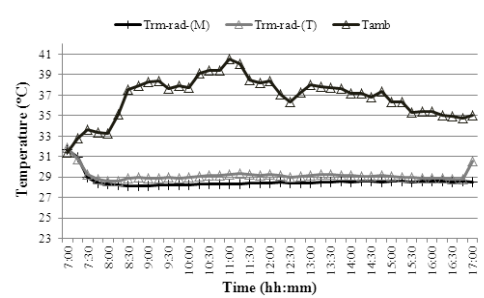

(b) Temperature of the room air 


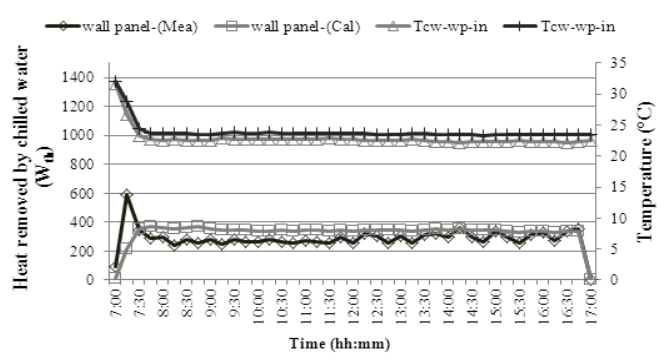

(c) Heat extraction and temperature of the cooling wall panel Fig. 2 Experimental results on 3 May 2013

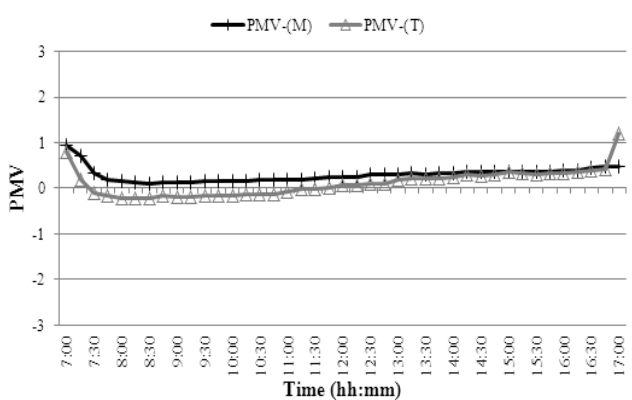

(d) Thermal comfort condition

Fig. 3(b) shows the variation of the air temperature measured in the radiant room (Trm-rad-(M)). By introducing cooled ventilation air, a significant drop of the room air temperature can be observed in the first half of an hour and then increased gradually by the heat gain through the room walls. It seems that cooling capacity of the radiant panels was not sufficient for the room. Fig. 3(c) shows the heat extraction rate and the temperature of the cooling wall panel. The panel temperature decreased sharply from $33^{\circ} \mathrm{C}$ to $22^{\circ} \mathrm{C}$ by the chilled water supply. The heat extraction rate was about $320 \mathrm{~W}_{\text {th }}$ or $55.6 \mathrm{~W} / \mathrm{m}^{2}$. Figure 3(d) shows a plot of the predicted mean vote from measurements PMV-(M). In the PMV calculations, air speed surround a subject was assumed $0.3 \mathrm{~m} / \mathrm{s}$ and using the data given in Table 1.

TRNSYS software was used to simulate the operation of the radiant cooling system, the temperature of the room air and interior wall surfaces, and the heat extraction rate of the cooling panels. From the plots in Fig. 3, it can be observed a good agreement between the measurements and the TRNSYS simulation.

Table 1. Data for TRNSYS simulations, 07:00-17:00 hours of 3rd May 2013

\begin{tabular}{|l|c|}
\hline \multicolumn{1}{|c|}{ Item } & Value \\
\hline Initial temperature of air and surfaces in the room $\left({ }^{\circ} \mathrm{C}\right)$ & 32.2 \\
\hline Area of the cooling panel $\left(\mathrm{m}^{2}\right)$ & 5.76 \\
\hline Flow rate of chilled water at cooling panel $(\mathrm{kg} / \mathrm{h})$ & 180 \\
\hline Ventilation air flow rate $(\mathrm{ACH})$ & 1 \\
\hline Ventilation air temperature at fan coil unit $\left({ }^{\circ} \mathrm{C}\right)$ & 22 \\
\hline Set temperature of chilled water at inlet to panels $\left({ }^{\circ} \mathrm{C}\right)$ & 22 \\
\hline Internal load, lighting $(\mathrm{W})$ & 92 \\
\hline Personal variables for PMV evaluation: & 1.0 \\
$-\quad$ Metabolic rate, Met & 0.5 \\
\hline$\quad$ Clothing insulation, Clo & \\
\hline
\end{tabular}

\subsection{Simulation analysis}

In the application of radiant cooling in the tropics, it is perceived that moisture condensation from the indoor air on the radiant panel is the major constraint that limits its cooling performance. In this study, a dehumidification system using a fan coil unit (FCU) was equipped with the radiant cooling system for reducing moisture of the room air through the ventilation. TRNSYS program was used to simulate the thermal condition in the radiant cooling room when the radiant cooling system operated under tropical climate and with different operating parameters. In the simulation, the system operating parameters to be varied are (i) temperature of the chilled water supplied to the radiant panels, and (ii) flow rate of and (iii) temperature of the ventilation air. From the simulations, the optimal operating parameters that maximize the thermal comfort can be determined. Table 2 shows the parameter values for yearly simulation study. In the simulation, chilled water temperature and ventilation rate and ventilation air temperature were varied. 
Table 2. Assumptions of the simulation for radiant cooling

\begin{tabular}{|l|c|}
\hline \multicolumn{1}{|c|}{ Category } & Input data \\
\hline Geographical location & $13.57^{\circ} \mathrm{N}, 100.5^{\circ} \mathrm{E}$ \\
\hline Ventilation rates $(\mathrm{kg} / \mathrm{h})$ & Varied $(30,45,60)$ \\
\hline Ventilation air temperature $\left({ }^{\circ} \mathrm{C}\right)$ & Varied $(19,20,21)$ \\
\hline Chilled water temperature $\left({ }^{\circ} \mathrm{C}\right)$ & Varied $(20,21,22)$ \\
\hline Flow rate of supply chilled water $(\mathrm{kg} / \mathrm{h})$ & $132(2.21 / \mathrm{min})$ \\
\hline Area of radiant panel $\left(\mathrm{m}^{2}\right)$ wall/ceiling & $5.76 / 5.76$ \\
\hline Daytime occupancy & $07: 00$ to $17: 00$ \\
$-\quad$ Duration hour (hrs) & 65 \\
Internal load $(\mathrm{W})$ & $55 / 40$ \\
Human (Seated, very light writing) (W/person) & \\
$\quad$ Sensible heat / Latent heat & $60 \% / 40 \% / 0$ \\
Light (1 lamp, W) & 1.2 \\
$\quad$ Radiative part/Convective part/Humidity & 0.6 \\
Metabolic rate of occupant (met) & \\
Clothing insulation (clo) & \\
\hline
\end{tabular}

Due to the limitation of the space, only the simulation results for the most critical period of hot and humid climate are presented. Fig. 3(a) exhibits the thermal comfort condition in the room as functions of the system operating parameters: (i) temperature of the chilled water to radiant panel $\left(\mathrm{T}_{\mathrm{cw}}\right)$, (ii) flow rate of the ventilation $\left(\mathrm{V}_{\text {vent }}\right)$ and (iii) temperature of the ventilation air $\left(\mathrm{T}_{\text {vent }}\right)$. From the plot, the temperature of the chilled water was varied from $20^{\circ} \mathrm{C}-22^{\circ} \mathrm{C}$, temperature of the ventilation air was varied from $19^{\circ} \mathrm{C}-21^{\circ} \mathrm{C}$ and the flow rate of the ventilation air was varied for $30 \mathrm{~kg} / \mathrm{h}, 45 \mathrm{~kg} / \mathrm{h}$, and $60 \mathrm{~kg} / \mathrm{h}$. The trend lines in the figure illustrate that the lower temperature of chilled water supply gives the longer period of thermal comfort in the room. The similar effect is also obtained by increasing the flow rate of and decreasing the temperature of the ventilation air. Other than the chilled water temperature, the ventilation performs its significance on the improvement of the thermal comfort. At $\mathrm{T}_{\mathrm{cw}}=20^{\circ} \mathrm{C}$, changing $\mathrm{T}_{\text {vent }}=21$ and $\mathrm{V}_{\text {vent }}=30 \mathrm{~kg} / \mathrm{h}$ to $\mathrm{T}_{\text {vent }}=20$ and $\mathrm{V}_{\text {vent }}=60 \mathrm{~kg} / \mathrm{h}$, the period that the room meet comfort condition increases from $60 \%$ to $90 \%$ of the daytime. In the plot, up to $90 \%$ of the time the thermal comfort can be achieved when $\mathrm{T}_{\mathrm{cw}}, \mathrm{T}_{\text {vent }}$ and $\mathrm{V}_{\text {vent }}$ are set at $20^{\circ} \mathrm{C}, 19^{\circ} \mathrm{C}$, and $60 \mathrm{~kg} / \mathrm{h}$, respectively.

Fig. 3(b) exhibits the percentage of time that condensation is occurred for the different operating parameters. It can be observed that to avoid the condensation, higher rate of the dehumidified ventilation is required. From the simulations, it seems that $\mathrm{V}_{\text {vent }}$ of $60 \mathrm{~kg} / \mathrm{h}$ or $2 \mathrm{ACH}$ is sufficient. As well, the value of $\mathrm{T}_{\mathrm{cw}}$ should be set at $2^{\circ} \mathrm{C}$ above the value of $\mathrm{T}_{\text {vent }}$ to warrantee no condensation. For the optimal operating point of $\mathrm{T}_{\mathrm{cw}}=20^{\circ} \mathrm{C}, \mathrm{T}_{\text {vent }}=19^{\circ} \mathrm{C}$, and $\mathrm{V}_{\text {vent }}=60 \mathrm{~kg} / \mathrm{h}$, there is no condensation during the system operation.
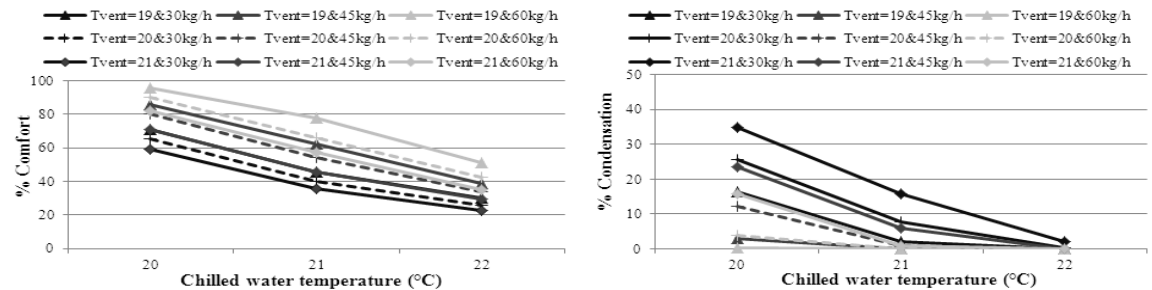

(a) Thermal comfort as functions of $\mathrm{T}_{\mathrm{cw}}, \mathrm{T}_{\mathrm{vent}}$, and $\mathrm{V}_{\mathrm{vent}}$

(b) Condensation as functions of $\mathrm{T}_{\mathrm{cw}}, \mathrm{T}_{\mathrm{vent}}$, and $\mathrm{V}_{\mathrm{vent}}$

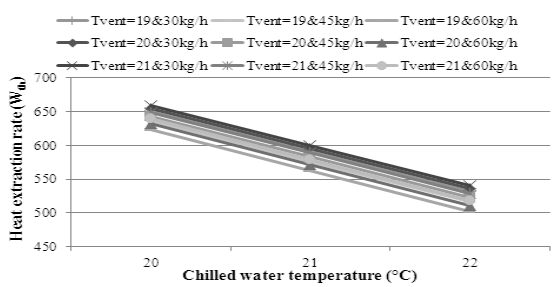

(c) Heat extraction rate at the radiant panels

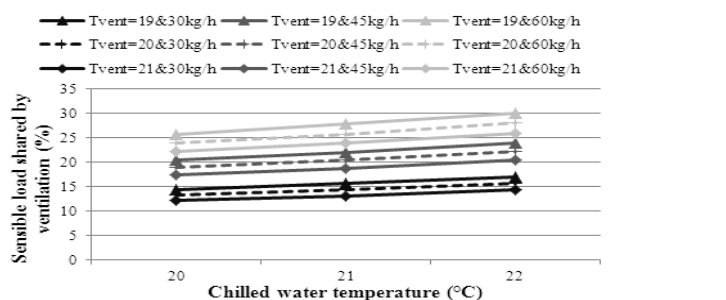

(d) Sensible load shared by the ventilation

Fig. 3 Yearly simulation results from TRNSYS software 
Fig. 3(c) exhibits the rate of heat extraction by the radiant panels at different operating parameters. From the plot, the chilled water temperature is the major influencing factor to the heat extraction rate. Reducing $\mathrm{T}_{\mathrm{cw}}$ from $22^{\circ} \mathrm{C}$ to $20^{\circ} \mathrm{C}$ will increase the rate of heat extraction from about $550 \mathrm{~W}$ to $650 \mathrm{~W}$ or about $18.2 \%$. As the surface area of the panels, the performance to extract heat of the panel is approximately $112.8 \mathrm{~W} / \mathrm{m}^{2}$ at $\mathrm{T}_{\mathrm{cw}}$ of $20^{\circ} \mathrm{C}$. Temperature and flow rate of the ventilation air are less effect compared to the chilled water temperature.

To dehumidify the ventilation air, the fan coil unit reduces the temperature of the air below its dew point in order to condense moisture from the air. Under this operation, the ventilation air also shares some fraction of the sensible load. It should be noted that the ventilation air handle with the whole latent load of the room. Fig. 3(d) illustrates the share of sensible load of the space by the ventilation air. The sensible load share by the ventilation is dependent on all operating parameters $T_{c w}, T_{\text {vent }}$ and $V_{\text {vent }}$. Increase of $T_{c w}$ reduces the performance of heat extraction by the panel, thus it results in the increase of the sensible load share by the ventilation. Reducing of $\mathrm{T}_{\text {vent }}$ and increasing of $\mathrm{V}_{\text {vent }}$ produce the similar result. From the simulation, the ventilation would share the sensible load from $12 \%$ upto $30 \%$ depended on the operating conditions.

\section{Conclusions}

Application of radiant cooling for thermal comfort in buildings was studied for real tropical climate of Thailand. The results from this study show that integration of a dehumidification system with the radiant cooling system is the solution for application of the radiant cooling for tropical climate. With the dehumidification system, the moisture content of the room air can be reduced by the ventilation, so lower temperature of chilled water (i.e $20^{\circ} \mathrm{C}$ ) can be supplied to the panels without condensation. In this study, there is no control system for supplying chilled water to the radiant panels and to the dehumidification unit. This limits the thermal comfort to be achieved by the system. Installation of a control system with suitable and logical algorithm is necessary for the radiant cooling system. The results for a series of whole-year simulations showed that the ventilation rate, the ventilation air temperature and the chilled water temperature were important parameters to achieve thermal comfort for building space.

\section{References}

[1] M. F. Brunk. Cooling ceilings-an opportunity to reduce energy costs by way of radiant cooling. ASHRAE Transactions: Symposia, 1993, DE-93-2-1: 479-487.

[2] A. M. Hamed. Desorption characteristics of desiccant bed for solar dehumidification /humidification air conditioning systems, Renewable Energy, 2003;28: 2099-2111.

[3] C.Stetiu. Energy and peak power savings potential of radiant cooling systems in US commercial buildings, Energy and Buildings. 1999; 30:127 -138.

[4] J. L. Niu, L. Z. Zhang, and H. Zuo. Energy saving potential of chilled-ceilingcombined with desiccant cooling in hot and humid climates, Energy and Buildings. 2002; 34: 487-495.

[5] S. A. Mumma. Ceiling panel cooling systems, ASHRAE Journal. November, 2001:2832.

[6] Jae-Han Lima. Jae-Hun Joa, Application of the control methods for radiant floor cooling system in residential buildings. Building and Environment, 2006;41:60-73.

[7] EN ISO 7730. Moderate thermal environments determination of the PMV and PPD indices and specification of the conditions for thermal comfort, ISO Geneva. 1994.

\section{Authors Information}

\begin{tabular}{|c|c|c|c|c|}
\hline Author name & Title & Membership & Contact & Author affiliation \\
\hline Satinee Wongkee & Miss. & $\begin{array}{l}\text { associate architect, } \\
\text { Architect Council of } \\
\text { Thailand License } \\
\text { G.V. 394.eh }\end{array}$ & $\begin{array}{l}\text { n_satinee@ hotmail.com } \\
\text { Tel+66892061151 }\end{array}$ & $\begin{array}{l}\text { The Joint Graduate School of } \\
\text { Energy and Environment King } \\
\text { Mongkut's University of } \\
\text { Technology Thonburi, } \\
\text { Bangkok 10140, Thailand }\end{array}$ \\
\hline
\end{tabular}




\begin{tabular}{|l|l|l|l|l|}
\hline $\begin{array}{c}\text { Surapong } \\
\text { Chirarattananon }\end{array}$ & $\begin{array}{c}\text { Prof. } \\
\text { Dr. }\end{array}$ & $\begin{array}{c}\text { senior member, } \\
\text { Institute of Electrical } \\
\text { and Electronics } \\
\text { Engineers (USA.). }\end{array}$ & $\begin{array}{c}\text { surapong@jgsee.kmutt.ac.th } \\
\text { Tel+ 66-2-4708309 to 10 } \\
\# 4147\end{array}$ & $\begin{array}{c}\text { The Joint Graduate School of } \\
\text { Energy and Environment King } \\
\text { Mongkut's University of } \\
\text { Technology Thonburi, } \\
\text { Bangkok 10140, Thailand }\end{array}$ \\
\hline $\begin{array}{l}\text { Pipat } \\
\text { Chaiwiwatworakul }\end{array}$ & Dr. & $\begin{array}{l}\text { associate mechanical } \\
\text { engineer, Controlled- } \\
\text { Engineer License } \\
\text { G.V. 10553. }\end{array}$ & $\begin{array}{l}\text { pel+66-2-4708309 to 10 } \\
\text { Telith }\end{array}$ & $\begin{array}{l}\text { The Joint Graduate School of } \\
\text { Energy and Environment King } \\
\text { Mongkut's University of } \\
\text { Technology Thonburi, } \\
\text { Bangkok 10140, Thailand }\end{array}$ \\
\hline
\end{tabular}

*S.E.-Senior Engineer; ** Member of IEEE-Fellow/Senior member/Member 